\title{
Platelet-Rich Plasma Injections In The Management Of Chronic Tendinopathies
}

\author{
Dr. L K Swamy*, Dr. A K Mishra*****, Dr. B K Sadangi**** Dr. S K \\ Hota $^{* * *}$, Dr. S K Behera***, Dr. S Patra*
}

\begin{abstract}
PRP injections have been proposed as a promising alternative for treating tendinopathies. Platelets release various cytokines and growth factors which promote angiogenesis, tissue remodeling, and wound healing. In this studyPRP prepared by drawing blood from patient, centrifuging it, $\operatorname{prp}(3$ to 10 times of the whole blood) will be injected over pathological tendon site over maximum point of tenderness, followed by immobilization of the part for 3 days, followed by eccentric loading exercise for 6 weeks and results assessed clinically,visual analogue scale at regular interval . PRP injections will be widely accepted by the patient as prepared from patients own blood and risk of adverse effect is minimal. Platelets have known roles in coagulation, inflammatory processes, and immunity modulation. Moreover, during degranulation, platelets release various cytokines and growth factors(vascular endothelial growth factors, platelet derived growth factors, transforming growth factors B. Insulin like growth factor 1 and hepatocyte growth factors) which promote angiogenesis, tissue remodeling, and wound healing Tendinopathies are chronic affections of the attachments of muscles to the bones.
\end{abstract}

\section{Introduction}

Tendinopathy refers to a triad of pain, swelling and decreased activity. Tendon related injuries are classified as tendinitis during acute inflammatory process and tendinosis when the healing become chronically impaired, clinicians are increasingly using the term tendinopathy to refer tendon disorders without a specific pathology, and chronic tendinopathy for cases that are refractory to conventional treatment. Common tendinopathies are epicondylitis, rotator cuff tendinopathy, patellar tendinopahy, achilles tendinopathy These have traditionally been treated conservatively by activity restriction, nonsteroidal anti-inflammatory drugs, physical therapy and judicious use of orthotics. Unresponsive patients are being treated by locally acting steroid injections with varied results. Surgical options are used sparingly when indicated. Platelet rich plasma has been tried by various researchers with the aim of a biological cure with minimal side effects and has shown promising results.Sports related injuries among professional and recreational athletes are increasingly encountered and diagnosed and demand a quick return to preinjury level of sporting activities. "'Orthobiologics", refers to the use of biological substances to help musculoskeletal injuries heal quicker. They are used to improve the healing of fractured bones and injured muscles, tendons and ligaments and are derived from substances that are naturally found in body. ${ }^{2}$ When they are used in concentrations many times the normal, they can potentially help speed up the healing processes. The substances include bone grafts, autologous blood, platelet-rich plasma (PRP), autologous conditioned serum and stem cells. ${ }^{2}$ Bone grafts act by their osteoinductive, osteoconductive and osteogenic properties to stimulate new bone formation and have no effect on the healing of muscles, tendons and ligaments. ${ }^{3}$ On the other hand, autologous blood, PRP and autologous conditioned serum deliver growth factors to the diseased areas to stimulate the repair process. ${ }^{4-6}$ Platelet-rich plasma (PRP) is defined as a sample of autologous blood with concentrations of platelets above baseline values. ${ }^{26}$ Platelets play an instrumental role in the normal healing response via the local secretion of growth factors and recruitment of reparative cells. ${ }^{59} \mathrm{This}$ study is conducted to know the effect of platelet rich plasma injection in the management of chronic tendinopathy in the Department of orthopaedics, M.K.C.G Medical College, Berhampur from 2014 to 2016.

\section{Aims And Objectives:}

To evaluate the efficacy of autologous platelet-rich plasma injection in chronic tendinopathies in terms of relief of symptoms,retention of maximum functional activity, Return to normal work.

\section{Inclusion criteria:}

All patients presenting with chronic tendinopathies like rotator cuff tendiopathy, epicondylities, achilles tendinopathy who have failed to improve even after three months of conservative management as outlined above.Men and women between 18 and 75 years of age with tendinopathy for $>3$ months not resolved with conventional treatmentThat include epicondylitis , rotator cuff tendinopathy, Achilles tendinopathy 


\section{Exclusion criteria:}

Patients having sensory or neurologic complaints affecting the specified region.Platelet disorder, coagulation disorder, pregnancy, major systemic illness like diabetes, rheumatoid arthritis, fibromyalgia, autoimmune disorders, any condition required strict antiplatelet or anticoagulation therapy.,drop out case

\section{Pre-injection assessment and preparation}

Patients with platelet count less than 1 lakh per millimeters were deferred for 3 weeks and were advised treatment for underlying cause of thrombocytopenia.The deferred patients were not taken for platelet rich plasma preparation till they achieved normal platelet count.Patients having thrombocyte count more than 1 lakh per millimeter were accepted for platelet rich plasma preparation.Patient's blood was taken from ante-cubital vein preferably from left, in tri-sodium citrate vacutainer $(3.8 \%)$ under sterile precautions directly from vein to vacutainer without opening the vacutainer. Autologous blood was collected in four vacutainer vials (approx. 12 $\mathrm{ml}$ ) for unilateral tendinopathy. The initial separation of plasma was done by standing method (vial was left in standing position for 1hour). After 1hour the vacutainer vials were spun at speed of 1600 round per minute for duration of one minute. Platelet rich plasma (PRP) wasseen as the top layer in vial vials followed by yellow buffy coat rich in white blood cells and red blood cell sediment at the bottom.One vial of every patient was used to check quality of platelet rich plasma. Plasma which contained platelet count more than 2.5 times of the patient's blood platelet counts were accepted for injection. This used vial was discarded. One $\mathrm{cm}$ plasma of (approx. 0.8-1 ml) which was just above yellow buffy layer was taken from by opening the top cork in a sterile $10 \mathrm{ml}$ syringe and used for injection. Approx $1 \mathrm{ml}$ of platelet rich plasma was mixed with $0.5 \mathrm{ml}$ lignocaine and used for injection in one tendon.Usually four vial for bilateral and two vials for unilateral cases were adequate. However one to two excess vials preferred were to maintain plasma volume adequacy for injection even in situation error in preparation of plasma, such as hemolysis due mechanical injury to red blood cell during blood withdrawal from patient.

\section{Platelet rich plasma Injection}

The affected part was cleaned with savlon and painted povidine iodine.and drapped.Approx. $1.5 \mathrm{ml}$ of mixture of platelet rich plasma and lignocaine was injected in at maximum tender point for epicodylitis and Achilles tendinopathy, and $1 \mathrm{~cm}$ below the angle of acromion for RCT. The injection was given with $22 \mathrm{G}$ needle over the part via a peppering technique (single skin entry, partially withdrawing the needle, redirecting and making multiple penetrations to the seath). After injection the part were immobilized for 3 days with appropriate splints \& patients were advised to avoid weight bearing sports activity such as running or jumping and heavy works such as lifting of heavy weights for at least four weeks. Nonsteroidal anti-inflammatory drugs were usually avoided because these drugs may interfere in post injection inflammatory healing process.

\section{Pre-injection pain assessment}

Visual Analogue Score (VAS) was used to assess pain before injection.All post injection patient were regularly reassessed clinically and for pain improvement with VAS and return to sports activity and heavy work at 1 month, 3 month and 6 month post injection

\section{Analysis}

Data analysis was performed using SPSS version 20. Values are presented as Mean \pm Standard deviation and standard error of mean. Categorical and Continuous variables were compared using appropriate tests. $p<0.05$ is considered statistically significant. Adjusted odds ratio and $95 \%$ confidence interval (CIs) will be computed for significant factors.

\section{Observation}

A total of 50 patients presenting with complaint of chronic tendinopathy, who did not respond to conservative treatment for 3 months, were included in the study. We encounter total eighteen patients of lateralepicondylitis, nine medial-epicondylitis, twelve rotator cuff tendinopathy and eleven patients of Achilles tendinopathy. Patients with these tendinopathy were advised for autologous platelet rich plasma injection. Advantages and disadvantage (explained in earlier) of platelet rich plasma therapy was explained. 50 of these patients gave valid informed and written consent. 
Table 1 (VAS) for lateral epicondylitis

Inference: Mean visual analogue score of all lateral epicondylitis at pre injection, at 1 month, 3 month, and 6 month post-injection were 7.55, 6.29, 3 and 1.05 respectively. These values show deceased post injection values.

\begin{tabular}{|l|l|l|l|l|l|}
\hline & & $\begin{array}{l}\text { Minimum } \\
\text { Score }\end{array}$ & $\begin{array}{l}\text { Maximum } \\
\text { score }\end{array}$ & Mean & Std. Deviation \\
\hline \multirow{5}{*}{ VAS } & Pre-Injection & 6 & 9 & 7.55 & .7838 \\
\cline { 2 - 7 } & 1 Month Post-Injection & 3 & 8 & 6.29 & 1.2628 \\
\cline { 2 - 7 } & 3 Month Post-Injection & 0 & 6 & 3 & 1.878 \\
\cline { 2 - 7 } & 6 Month Post-Injection & 0 & 6 & 1.05 & 1.696 \\
\hline
\end{tabular}

Table 2 Descriptive Statistics: Visual analogue pain score (VAS) for medial epicondylitis

\begin{tabular}{|l|l|l|l|l|l|}
\hline \multirow{2}{*}{} & & $\begin{array}{l}\text { Minimum } \\
\text { score }\end{array}$ & $\begin{array}{l}\text { Maximum } \\
\text { score }\end{array}$ & Mean & Std. Deviation \\
\hline \multirow{4}{*}{ VAS } & Pre-Injection & 7 & 9 & 7.88 & .6009 \\
\cline { 2 - 7 } & 1 Month Post-Injection & 4 & 7 & 5.77 & 0.9444 \\
\cline { 2 - 7 } & 3 Month Post-Injection & 0 & 5 & 2.88 & 1.833 \\
\cline { 2 - 7 } & 6 Month Post-Injection & 0 & 4 & 1.444 & 1.589 \\
\hline
\end{tabular}

INFERENCE: Mean visual analogue score of all medial epicondylitis at pre injection, at 1 month, 3 month, and 6 month post-injection were 7.88, 5.77, 2.88 and 1.44 respectively. These values show deceased post injection values.

Table 3 Descriptive Statistics: Visual analogue pain score (VAS) for rct

\begin{tabular}{|l|l|l|l|l|l|}
\hline & & Minimum score & Maximum score & Mean & Std. Deviation \\
\hline \multirow{5}{*}{ VAS } & Pre-Injection & 8 & 9 & 8.25 & 0.425 \\
\cline { 2 - 7 } & 1 Month Post-Injection & 5 & 7 & 5.75 & 0.753 \\
\cline { 2 - 7 } & 3 Month Post-Injection & 2 & 5 & 3.58 & 0.792 \\
\cline { 2 - 7 } & 6 Month Post-Injection & 0 & 5 & 1.25 & 1.764 \\
\hline
\end{tabular}

INFERENCE: Mean visual analogue score of all rotator cuff tendinopathy at pre injection, at 1 month, 3 month, and 6 month post-injection were 8.25, 5.75, 3.58 and 1.25 respectively. These values show deceased post injection values.

Table 4 Descriptive Statistics: Visual analogue pain score(VAS) for AT

\begin{tabular}{|l|l|l|l|l|l|}
\hline \multirow{2}{*}{} & & Minimum score & Maximum score & Mean & Std. Deviation \\
\hline \multirow{4}{*}{ VAS } & Pre-Injection & 7 & 9 & 8 & 0.447 \\
\cline { 2 - 7 } & & & 7 & 5.54 & 0.82 \\
\cline { 2 - 7 } & 3 Month Post-Injection & 4 & 4 & 3.09 & 1.136 \\
\cline { 2 - 7 } & 6 Month Post-Injection & 0 & 4 & 1.27 & 1.555 \\
\hline
\end{tabular}


INFERENCE: Mean visual analogue score of all Achilles tendinopathy at pre injection, at 1 month, 3 month, and 6 month post-injection were 8, 5.54, 3.09and 1.27 respectively. These values show deceased post injection values.

Table 5 To check significance difference of mean visual analogues pain score, paired t test were setup between various possible groups as given below for lateral epicondylitis

\begin{tabular}{|l|l|l|l|l|}
\hline \multicolumn{2}{|l|}{ MEAN VISUAL ANALOGUES PAIN SCORE } & Mean diff. & T value & P value \\
\hline Pre-Injection & 1 Month Post-Injection & 1.777 & 6.20 & .00004 \\
\hline Pre-Injection & 3month Post-Injection & 4.555 & 11.44 & .0000 \\
\hline Pre-Injection & 6 Month Post-Injection & 6.500 & 17.044 & .0000 \\
\hline 1 Month Post-Injection & 3month Post-Injection & 2.777 & 5.2 & .0000 \\
\hline 1 Month Post-Injection & 6 Month Post-Injection & 4.722 & 9.7 & .0000 \\
\hline 3month Post-Injection & 6 Month Post-Injection & 1.944 & 4.43 & .0001 \\
\hline
\end{tabular}
value $<0.05$ )

INFERENCE: There was significant difference of mean visual scores of pain in all given group pair ( $\mathrm{p}$

Table 6 .To check significance difference of mean visual analogues pain score, paired t test were setup between various possible groups as given below for medial epicondylitis

\begin{tabular}{|l|l|l|l|l|}
\hline \multicolumn{2}{|l|}{ MEAN VISUAL ANALOGUES PAIN SCORE } & $\begin{array}{l}\text { Mean } \\
\text { diff. }\end{array}$ & T value & P value \\
\hline Pre-Injection & 1 Month Post-Injection & 2.11 & 6.8 & .0001 \\
\hline Pre-Injection & 3month Post-Injection & 5 & 10 & .0000 \\
\hline Pre-Injection & 6 Month Post-Injection & 6.44 & 11.60 & .0000 \\
\hline 1 Month Post-Injection & 3month Post-Injection & 2.88 & 4.27 & .0027 \\
\hline 1 Month Post-Injection & 6 Month Post-Injection & 4.33 & 6.7 & .0000 \\
\hline 3month Post-Injection & 6 Month Post-Injection & 1.44 & 2.87 & .0200 \\
\hline
\end{tabular}

Inference: There was significant difference of mean visual scores of pain in all given group pair ( $p$ value $<0.05)$.

Table 7 To check significance difference of mean visual analogues pain score, paired t test were setup between various possible groups as given below for RCT

\begin{tabular}{|c|c|c|c|c|}
\hline \multicolumn{2}{|c|}{ MEAN VISUAL ANALOGUES PAIN SCORE } & Mean diff. & $\mathrm{T}$ value & $\mathrm{P}$ value \\
\hline Pre-Injection & 1 Month Post-Injection & 2.5 & 10.8 & .0000 \\
\hline Pre-Injection & 3month Post-Injection & 4.666 & 20.7 & .0000 \\
\hline Pre-Injection & 6 Month Post-Injection & 7 & 13.79 & .0000 \\
\hline $\begin{array}{l}1 \quad \text { Month Post- } \\
\text { Injection }\end{array}$ & 3month Post-Injection & 2.166 & 6.73 & .0000 \\
\hline $\begin{array}{l}1 \quad \text { Month Post- } \\
\text { Injection }\end{array}$ & 6 Month Post-Injection & 4.5 & 7.10 & .0000 \\
\hline $\begin{array}{l}\text { 3month } \\
\text { Injection }\end{array}$ & 6 Month Post-Injection & 2.33 & 4.84 & .0005 \\
\hline
\end{tabular}

INFERENCE: There was significant difference of mean visual scores of pain in all given RCT.

Table 8 To check significance difference of mean visual analogues pain score, paired t test were setup between various possible groups as given below for AT

\begin{tabular}{|l|l|l|l|l|}
\hline \multicolumn{2}{|l|}{} & Mean Diff. & T Value & P Value \\
\hline Pre-Injection & & & \\
\hline Pre-Injection & 1 Month Post-Injection & 2.45 & 7.86 & .0000 \\
\hline Pre-Injection & 3month Post-Injection & 4.90 & 12.52 & .0000 \\
\hline 1 Month Post-Injection & 6 Month Post-Injection & 6.72 & 12.06 & .0000 \\
\hline 1 Month Post-Injection & 3month Post-Injection & 2.45 & 5.4 & .0003 \\
\hline 3month Post-Injection & 6 Month Post-Injection & 4.27 & 9.97 & .0000 \\
\hline
\end{tabular}

INFERENCE: There was significant difference of mean visual scores of pain in all given AT. 
Table 9 Descriptive Statistics: Visual analogue pain score(VAS) for all tedinopathies in our study

\begin{tabular}{|l|l|l|l|l|l|}
\hline & & $\begin{array}{l}\text { Minimum } \\
\text { score }\end{array}$ & $\begin{array}{l}\text { Maximum } \\
\text { score }\end{array}$ & Mean & Std. Deviation \\
\hline \multirow{4}{*}{ VAS } & Pre-Injection & 6 & 9 & 7.88 & 0.6590 \\
\cline { 2 - 7 } & 1 Month Post-Injection & 3 & 8 & 5.72 & 0.990 \\
\cline { 2 - 7 } & 3 Month Post-Injection & 0 & 6 & 3.14 & 1.49 \\
\cline { 2 - 7 } & 6 Month Post-Injection & 0 & 6 & 1.22 & 1.61 \\
\hline
\end{tabular}

INFERENCE: Mean visual analogue score of all tendinopathies at pre injection, at 1 month, 3 month, and 6 month post-injection were 7.88, 5.72, 3.14 and 1.22 respectively. These values show deceased post injection values.

Table 10

\begin{tabular}{|l|l|l|l|l|}
\hline \multicolumn{2}{|l|}{ MEAN VISUAL ANALOGUES PAIN SCORE } & Mean diff. & T value & P value \\
\hline Pre-Injection & 1 Month Post-Injection & 2.16 & 14.45 & .0000 \\
\hline Pre-Injection & 3month Post-Injection & 4.74 & 24.5 & .0000 \\
\hline Pre-Injection & 6 Month Post-Injection & 6.6 & 28.1 & .0000 \\
\hline 1 Month Post-Injection & 3 month Post-Injection & 2.58 & 10.09 & .0000 \\
\hline 1 Month Post-Injection & 6 Month Post-Injection & 4.5 & 16.7 & .0000 \\
\hline 3month Post-Injection & 6 Month Post-Injection & 1.92 & 8.34 & .0000 \\
\hline
\end{tabular}

INFERENCE: There was significant difference of mean visual scores of pain in all chronic tendinopathy.

In this study arbitrarily we assumed patient with visual analogue pain score equal or less than 3 as satisfactory improvement of pain.

Table 11 Percentage of tendinopathie in which satisfactory improvement occurred

\begin{tabular}{|l|l|l|l|}
\hline \% of patients in which satisfactory improvement of pain \\
\hline & 1 month post-injection & 3 month post-injection & 6 month post-injection \\
\hline $\begin{array}{l}\text { Visual } \\
\text { analogue pain } \\
\text { score }\end{array}$ & $4 \%$ & $50 \%$ & $84 \%$ \\
\hline
\end{tabular}

INFERENCE: On basis of Visual analogue pain score, satisfactory improvement of pain at 1 month, 3 months and 6 month post injection were observed in $4 \%$, 50\% and $84 \%$ of tendinopathies respectively.

\section{Summary}

A total of 50 patients presenting with complaints of chronic tendinopathies who did not respond to conservative treatment for 3 months were included in the study. 56\% patients were male and $44 \%$ patients were female.in our study $18(36 \%), 9(18 \%), 12(24 \%)$ and $11(22 \%)$ of total patients belong to lateral epicondylitis, medial epicondylitis, rotator cuff tendinopathy and Achilles tendinopathy respectively.In this study, $33(66 \%)$ affected patients belong to right side and 17 (34\%) affected patients to left side. Mean age of male patient's was $42.39 \pm 6.14$ year. Mean age of female patient's was $41.89 \pm 5.6$ year. Most common activity levels in male patients were heavy or longstanding and in female patients were sedentary. There are no significant differences of mean in male and female pain score groups at Pre-injection level.There was no 
significant mean difference in preinjection pain scores on basis daily activity level ( $\mathrm{p}$ value $>0.05$ ). Mean visual analogue scores of all affected patients at 1 month, 3 month, and 6 month post-injection follow up showed improvement. Significant difference of mean visual scores of pain were observed.

There was no significant mean difference in male and female patient's pain score.These were no significant mean difference in right and left side pain scores.Satisfactory improvements were shown in $84 \%$ of tendinopathies at 6 month follow up on basis of VAS .Satisfactory and unsatisfactory improvement patients had similar profile like age, weight.

\section{Conclusion}

The results of this study indicate that PRP injection has a role to play in the management of chronic tendinopathies. This technique was efficient in approximately $84 \%$ affected patients at 6 month follow-up. PRP is simple to acquire and prepare and is also cost effective . Hence it provides satisfactory intermediate and long term results in term of pain relief. It seems a safe clinical procedure. Indeed we had no reported side effects. However larger data set and longer follow up are required to conclude definitive role of PRP. We believe that these initial encouraging results now warrant further investigation, in particular with the use of a prospective randomized controlled trial $(\mathrm{RCT})$.

\section{Limitations}

There are some limitations of the study that should be considered.It is small no patients study, only 50 patients. Larger studies would be required to further validate efficacy of autologous platelet rich plasma injection in chronic tendinopathy with failed conservative management.This study did not include any control group for comparison of PRP injection result. Studies with control group of proven treatment modality would be required to further validate efficacy of PRP.In this study PRP preparation was done with ordinary technique. Further Studies with better PRP preparation technique would be required to further validate efficacy of PRP

\section{Discussion}

Chronic tendinopathies are common clinical problem with many available treatment modalities. Traditional treatments include rest, analgesics and physiotherapy. Injections, particularly corticosteroids, are given in very acute situations and for cases unresponsive to conservative methods. Corticosteroids offer a quick fix for pain relief in the acute phase but have limited effect in chronic cases with a significant fraction of patients having relapse and recurrence ${ }^{130}$. In chronic cases, surgery is the last resort with very unpredictable results. Recent years have seen an increase in the use of PRP in various clinical situations like epicondylitis, rotator cuff, patellar and calcaneal tendinopathies, and proximal plantar fascitis. This study was designed to evaluate the efficacy of PRP therapy for chronic tendinopathy. PRP contains a more concentrated amount of platelets than does whole blood. The rationale for using PRP is to increase tendon regenerative abilities with a high content of cytokines and cells, in hyper-physiologic doses, which should promote cellular chemotaxis, matrix synthesis, and proliferation. ${ }^{11}$ Degranulation of the alpha granules in platelets releases many different growth factors that can play a role in tissue regeneration processes. PRP represents a treatment option for many foot and ankle pathologies, including tendinopathy (Achilles, pe-roneal, posterior tibial, flexor hallucis longus, anterior tibial) and chronic ligamentous injury, such as plantar fascitis. ${ }^{10}$. Visual Analogue Scale (VAS) measure amount of pain that a patient feels ranges across a continuum from none to an extreme amount of pain. Operationally a VAS is usually a horizontal line, $100 \mathrm{~mm}$ in length, anchored by word descriptors at each end.

Mishra et al (2006) in their study of prp for lateral epicondylitis taken 15 patients of average age 48.1 yrs showed decreased VAS score(0-100) from 80.3 to $43.4(4 \mathrm{wk})$ to 32.0 (8wk) to 5.7 (6 months). Hechtman et al (2011) in their study of prp for lateral epicondylitis showed results of decreased vas score $>25 \%$ in $96 \%$ of patients at 1year.

Peerbooms et al. ${ }^{32}$ conducted a RCT with 100 patients lateral epicondylitis, 51 of whom received PRP injection and 49 received corticosteroid injections and reported better improvement with PRP over a period of 1 year. Gosens et al. ${ }^{33}$ followed up these patients for the subsequent year and reported a sustained improvement with PRP use in comparison to corticosteroids. Thanasas et al. ${ }^{17}$ have also shown encouraging results for PRP use compared to ABI in resistant tennis elbow patients.Randelli et al. ${ }^{36}$ conducted an uncontrolled pilot study of PRP augmentation along with arthroscopic rotator cuff repair. In their 14 patients injected with PRP activated with thrombin at the tendon footprint after repair, they reported statistically significant improvements in VAS. Owens et al. ${ }^{47}$ reported modest improvement in functional outcome in 10 patients who had received PRP injection for mid substance Achilles tendinopathy. Monto et al. ${ }^{48}$ reported clinical success in 28 out of 30 patients with recalcitrant Achilles tendinosis. The improvement noted was in the AOFAS score and the MR architecture of the tendon.

The present series also shows significant improvement in VAS in consecutive follow up at 1 month, 3 month, and 6 month of duration for lateral epicondylitis medial epicondylitis and rotator cuff tendinopathy and 
Achilles tendinopathy. Differences between mean pain score on follow up were statistically significant in every follow up interval. These results are comparable to previous studies.It was assumed, that patients with visual analogue pain score equal or less than 3. On the basis of Visual analogue pain score, satisfactory improvement of pain were observed in 4\%, 50\% and $84 \%$ of tendons at 1 month, 3month and 6month post injection respectively.At final follow up (at 6 month) approx. $84 \%$ of patient who received PRP in injection showed satisfactory improvementof pain.

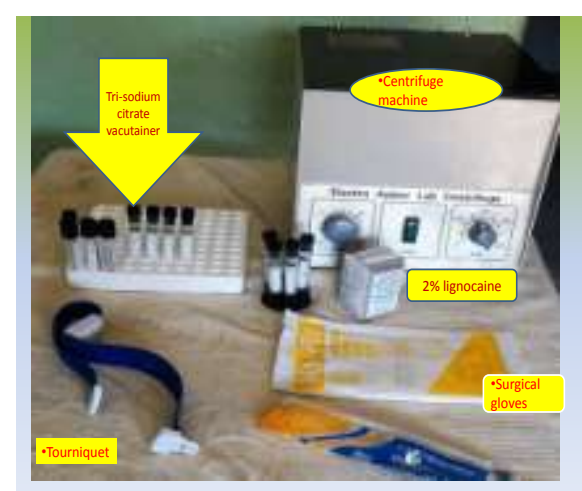

Figure 1 Requirements

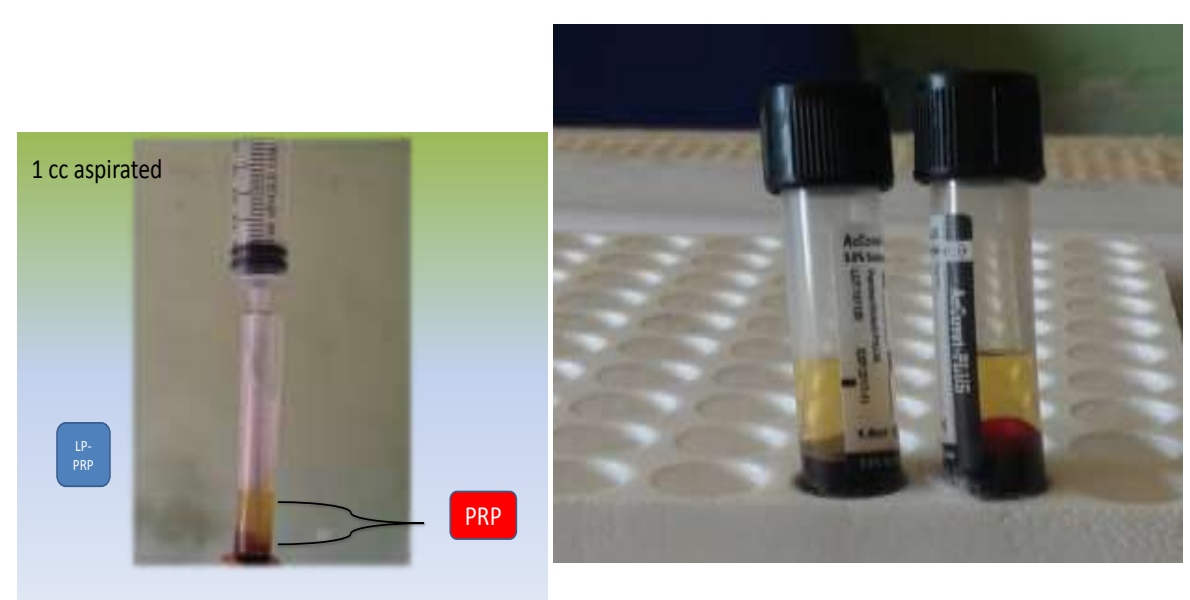

Figure 2 prp separated

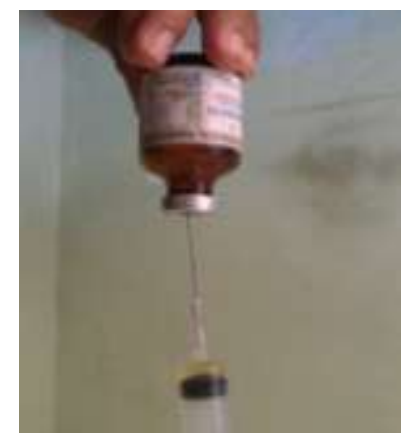

Figure 3 mixed with lignocane 

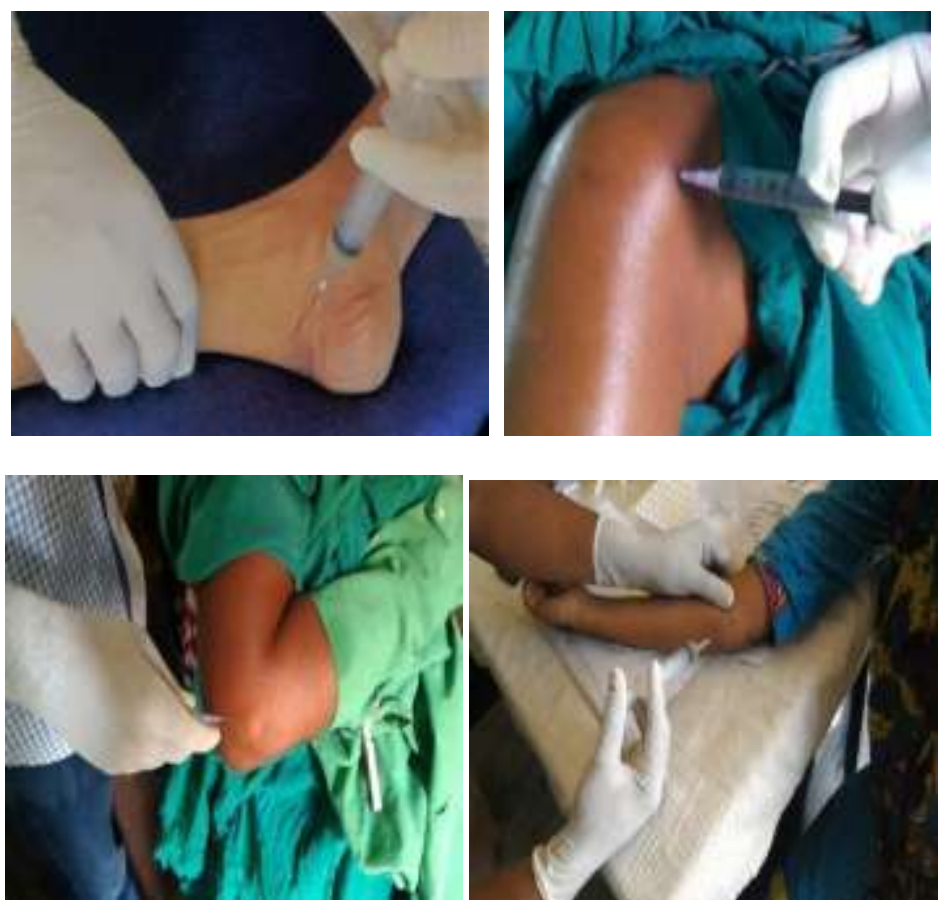

*PG Student, **Senior Resident, *** Asst. Professor,***Asso Professor, **** Professor

\section{Reference}

[1]. Kannus P, Natri A. Etiology and pathophysiology of tendon ruptures in sports. Scand J Med Sci Sports 1997;7:107-12.

[2]. Available from: http://orthoinfo.aaos.org/topic. cfm?topic=A00525 [Last accessed on 25th Nov. 2013].

[3]. Roberts TT, Rosenbaum AJ. Bone grafts, bone substitutes and orthobiologics: The bridge between basic science and clinical advancements in fracture healing. Organogenesis 2012;8:114-24.

[4]. Paoloni J, De Vos RJ, Hamilton B, Murrell GA, Orchard J. Platelet-rich plasma treatment for ligament and tendon injuries. Clin J Sport Med 2011;21:37-45

[5]. Wehling P, Moser C, Frisbie D, Mcllwraith CW, Kawcak CE, Krauspe R, et al. Autologous conditioned serum in the treatment of orthopedic diseases: The orthokine therapy. Bio Drugs 2007;21:323-32

[6]. Alsousou J, Thompson M, Hulley P, Noble A, Willett K. The biology of platelet-rich plasma and its application in trauma and orthopaedic surgery: A review of the literature. J Bone Joint Surg Br 2009;91:987-96.

[7]. Schmitt A, vanGriensven M, Imhoff AB, Buchmann S. Application of stem cells in orthopedics. Stem Cells Int 2012;2012:394962.

[8]. Leadbetter WB. Cell-matrix response in tendon injury. Clin Sports Med 1992;11:533-78.

[9]. Gelberman R, Goldberg V, An KN, BanesA. Tendon. In: Woo SL, Buckwalter JA, (editors). Injury and Repair of the Musculoskeletal Soft Tissues: Workshop, Savannah, Georgia, 1987. Park Ridge, Illinois: American Academy of Orthopaedic Surgeons; 1988. p. 1-40.

[10]. Filardo G, Kon E, Di Martino A, DiMatteo B, Merli ML, Cenacchi A, et al. Platelet-rich plasma vs hyaluronic acid to treat knee degenerative pathology: Study design and preliminary results of a randomized controlled trial. BMC Musculoskelet Disord 2012;13:229.

[11]. Gibble J, Ness P. Fibrin glue: The perfect operative sealant? Transfusion 1990;30:741-7.

[12]. Marx RE, Carlson ER, Eichstaedt RM, SchimmeleSR, Strauss JE, Georgeff KR. Platelet - rich plasma - Growth factor enhancement for bone grafts. Oral Surg Oral Med Oral Pathol Oral Radiol Endod 1998;85:638-46.

[13]. Edwards SG, Calandruccio JH. Autologous blood injections for refractory lateral epicondylitis. J Hand Surg Am 2003;28:272-8.

[14]. Connell DA, Ali KE, Ahmad M, Lambert S, Corbett S, Curtis M. Ultrasound-guided autologous blood injection for tennis elbow. Skeletal Radiol 2006;35:371-7.

[15]. Ozturan KE, Yucel I, Cakici H, Guven M, Sungur I. Autologous blood and corticosteroid injection and extracorporeal shock wave therapy in the treatment of lateral epicondylitis. Orthopedics 2010;33:84-91.

[16]. Creaney L, Wallace A, Curtis M, Connell D. Growth factor-based therapies provide additional benefit beyond physical therapy in resistant elbow tendinopathy: A prospective, double-blind, randomized trial of autologous blood injections versus platelet-rich plasma injections. Br J Sports Med 2011;45:966-71.

[17]. Thanasas C, Papadimitriou G, Charalambidis C, Paraskevopoulos I, Papanikolaou A. Platelet-rich plasma versus autologous whole blood for the treatment of chronic lateral elbow epicondylitis: A randomized controlled clinical trial. Am J Sports Med 2011;39:2130-4

[18]. Kazemi M, Azma K, Tavana B, RezaieeMoghaddam F, Panahi A. Autologous blood versus corticosteroid local injection in the short-term treatment of lateral elbow tendinopathy: A randomized clinical trial of efficacy. Am J Phys Med Rehabil 2010;89:660 - 7.

[19]. Suresh SP, Ali K, Jones H, Connell DA. Medial epicondylitis: Is ultrasound guided autologous blood injection an effective treatment? Br J Sports Med 2006;40:935-9.

[20]. James SL, Ali K, Pocock C, Robertson C, Walter J, Bell J, et al. Ultrasound guided dry needling and autologous blood injection for patellar tendinosis. Br J Sports Med 2007;41:518-21. 
[21]. Becker C, Heidersdorf S, Drewlo S, de Rodriguez SZ, Kramer J, Willburger RE. Efficacy of epidural perineural injections with autologous conditioned serum for lumbar radicular compression: An investigator-initiated, prospective, double-blind, referencecontrolled study. Spine (Phila Pa 1976) 2007;32:1803-8.

[22]. Moser CB, Jansen SA. Autologous conditioned serum (ACS) Injection compared to HA and saline injections for the treatment of knee OA. American Academy of Orthopedic Surgeons 74th Annual Meeting 2007; 14 - 18

[23]. Hernigou P, Mathieu G, Poignard A, Manicom O, Beaujean F, Rouard H. Percutaneous autologous bone-marrow grafting for nonunions. Surgical technique. J Bone Joint Surg Am 2006;88(Suppl 1 Pt 2):322-7.

[24]. Kotobuki N, Hirose M, Takakura Y, Ohgushi H. Cultured autologous human cells for hard tissue regeneration: Preparation and characterization of mesenchymal stem cells from bone marrow. Artif Organs 2004;28:33-9.

[25]. Harrison P, Cramer EM. Platelet alpha-granules. Blood Rev 1993;7:52-62.

[26]. Sanchez M, Anitua E, Azofra J, Andia I, Padilla S, Mujika I. Comparison of surgically repaired achilles tendon tears using plateletrich fibrin matrices. Am J Sports Med 2007;35:245-51.

[27]. Mishra A, Harmon K, Woodall J, Vieira A. Sports Medicine Applications of Platelet Rich Plasma. Curr Pharm Biotechnol 2012;13:1185-95.

[28]. Dragoo JL, Braun HJ, Durham JL, Ridley BA, Odegaard JI, Luong R, et al. Comparison of the acute inflammatory response of two commercial platelet-rich plasma systems in healthy rabbit tendons. Am J Sports Med 2012;40:1274-81.

[29]. McCarrel TM, Minas T, Fortier LA. Optimization of leukocyte concentration in platelet - rich plasma for the treatment of tendinopathy. J Bone Joint Surg Am 2012;94:e143 (1-8).

[30]. Taylor DW, Petrera M, Hendry M, The odoropoulos JS. A systematic review of the use of platelet-rich plasma in sports medicine as a new treatment for tendon and ligament injuries. Clin J Sport Med 2011;21:344-52.

[31]. Mishra A, Pavelko T. Treatment of chronic elbow tendinosis with buffered platelet rich plasma. Am J Sports Med 2006;34:1774-8.

[32]. Peerbooms JC, Sluimer J, Bruijn DJ, Gosens T. Positive effect of an autologous platelet concentrate in lateral epicondylitis in a double-blind randomized controlled trial: Platelet-rich plasma versus corticosteroid injection with a 1-year followup. Am J Sports Med 2010;38:255-62.

[33]. Gosens T, Peerbooms JC, van Laar W, den Oudsten BL. Ongoing positive effect of platelet-rich plasma versus corticosteroid injection in lateral epicondylitis: A double-blind randomized controlled trial with 2-year followup. Am J Sports Med 2011;39:1200 -8 .

[34]. Chaudhury S, de La Lama M, Adler RS, Gulotta LV, Skonieczki B, Chang A, et al. Platelet-rich plasma for the treatment of lateral epicondylitis: Sonographic assessment of tendon morphology and vascularity (pilot study). Skeletal Radiol 2013;42:91-7.

[35]. Randelli PS, Arrigoni P, Cabitza P, Volpi P, Maffulli N. Autologous platelet rich plasma for arthroscopic rotator cuff repair: A pilot study. Disabil Rehabil 2008;30:1584-9.

[36]. Randelli P, Arrigoni P, Ragone V, Aliprandi A, Cabitza P. Platelet rich plasma in arthroscopic rotator cuff repair: A prospective RCT study, 2-year followup. J Shoulder Elbow Surg 2011;20:518-28.

[37]. Rha DW, Park GY, Kim YK, Kim MT, Lee SC. Comparison of the therapeutic effects of ultrasound-guided platelet-rich plasma injection and dry needling in rotator cuff disease: A randomized controlled trial. Clin Rehabil 2013;27:113-22.

[38]. Weber SC, Kauffman JI, Parise C, Weber SJ, Katz SD. Platelet-Rich Fibrin Matrix in the Management of Arthroscopic Repair of the Rotator Cuff: A Prospective, Randomized, Double-Blinded Study. Am J Sports Med 2013;41:263-70.

[39]. Castricini R, Longo UG, De Benedetto M, Panfoli N, Pirani P, Zini R, et al. Platelet-rich plasma augmentation for arthroscopic rotator cuff repair: A randomized controlled trial. Am J Sports Med 2011;39:258-65.

[40]. Spaková T, Rosocha J, Lacko M, Harvanová D, Gharaibeh A. Treatment of knee joint osteoarthritis with autologous platelet-rich plasma in comparison with hyaluronic acid. Am J Phys Med Rehabil 2012;91:411-7.

[41]. Kon E, Mandelbaum B, Buda R, Filardo G, Delcogliano M, Timoncini A, et al. Platelet-rich plasma intraarticular injection versus hyaluronic acid viscosupplementation as treatments for cartilage pathology: From early degeneration to osteoarthritis. Arthroscopy 2011;27:1490-501.

[42]. Cerza F, Carnì S, Carcangiu A, Di Vavo I, Schiavilla V, Pecora A, et al. Comparison Between Hyaluronic Acid and Platelet-Rich Plasma, Intraarticular Infiltration in the Treatment of Gonarthrosis. Am J Sports Med 2012;40:2822-7.

[43]. Patel S, Dhillon MS, Aggarwal S, Marwaha N, Jain A. Treatment with platelet-rich plasma is more effective than placebo for knee osteoarthritis: A prospective, double-blind, randomized

[44]. trial. Am J Sports Med 2013;41:356-64.

[45]. deJonge S, de Vos RJ, Weir A, van Schie HT, Bierma-Zeinstra SM, Verhaar JA, et al. One-year followup of platelet-rich plasma treatment in chronic Achilles tendinopathy: A double-blind randomized placebo-controlled trial. Am J Sports Med 2011;39:16239.

[46]. De VosRJ, Weir A, Tol JL, Verhaar JA, Weinans H, van Schie HT. No effects of PRP on ultrasonographic tendon structure and neovascularisation in chronic midportion Achilles tendinopathy. Br J Sports Med 2011;45:387-92.

[47]. Owens RF Jr, Ginnetti J, Conti SF, Latona C. Clinical and magnetic resonance imaging outcomes following platelet rich plasma injection for chronic mid-substance Achilles tendinopathy. Foot Ankle Int 2011;32:1032-9.

[48]. Monto RR. Platelet rich plasma treatment for chronic Achilles tendinosis. Foot Ankle Int 2012;33:379-85

[49]. Schepull T, Kvist J, Norrman H, Trinks M, Berlin G, Aspenberg P. Autologous platelets have no effect on the healing of human achilles tendon ruptures: A randomized single-blind study. Am J Sports Med 2011;39:38-47.

[50]. Filardo G, Kon E, Della Villa S, Vincentelli F, Fornasari PM, Marcacci M. Use of platelet-rich plasma for the treatment of refractory jumper's knee. Int Orthop 2010;34:909-15.

[51]. Gosens T, Den Oudsten BL, Fievez E, van 't Spijker P, Fievez A. Pain and activity levels before and after platelet-rich plasma injection treatment of patellar tendinopathy: A prospective cohort study and the influence of previous treatments. Int Orthop 2012;36:1941-6.

[52]. Vetrano M, Castorina A, Vulpiani MC, Baldini R, Pavan A, Ferretti A. Platelet-Rich Plasma Versus Focused Shock Waves in the Treatment of Jumper's Knee in Athletes. Am J Sports Med 2013;41:795-803.

[53]. Malhotra R, Kumar V, Trikha A. Platelet Concentrate in Treatment of Non Union of Long Bones. In proceedings of AAOS Annual Meeting. Feb 2012. 
[54]. Available from: http://www.eternesseclinic.com/platelet- rich-plasma-therapy/[last accessed on 2013 Nov 25]

[55]. Available from: http://www.apollodermatologistdelhi.com/new_projects.html [last accessed on 2013 Nov 25].

[56]. Available from: http://orthopedics.about.com/od/injectio2/p/ prp.htm [last accessed on 2013 Nov 25].

[57]. Available from: http://www.usada.org/prohibited-list/ athlete-guide/[last accessed on 2013 Nov 25].

[58]. Guidelines for the Use of Platelet Rich Plasma Available from: http://www.cellmedicinesociety.org/icms-guidelines [last accessed on 2013 Nov 25].

[59]. Park YG, Han SB, Song SJ, Kim TJ, Ha CW. Platelet-rich plasma therapy for knee joint problems: Review of the literature, current practice and legal perspectives in Korea. Knee Surg Relat Res 2012;24:70-8.

[60]. Molloy T, Wang Y, Murrell G. The roles of growth factors in tendon and ligament healing. Sports Med 2003;33:381-94

[61]. Best TM, Garrett WE. Basic science of soft tissue: muscle and tendon. In: DeLee JC, Drez D (eds) Orthopaedic Sports Medicine. Philadelphia, PA: W.B. Saunders, 1994:1-45.

[62]. Kannus P, Jozsa L, Jarvinnen M. Basic science of tendons. In: Garrett WJ, Speer K, Kirkendall DT (eds) Principles and Practice of Orthopaedic Sports Medicine. Philadelphia, PA: Lippincott Williams and Wilkins, 2000:21-37.

[63]. O’Brien M. Structure and metabolism of tendons. Scandinavian Journal of Medicine and Science in Sports 1997;7:55-61.

[64]. Hess GP, Cappiello WL, Poole RM, Hunter SC. Prevention and treatment of overuse tendon injuries. Sports Medicine 1989;8:37184.

[65]. Jozsa L, Lehto M, Kannus P, et al. Fibronectin and laminin in Achilles tendon. Acta Orthopaedica Scandinavica 1989;60:469-71.

[66]. Tipton CM, Matthes RD, Maynard JA, et al. The influence of physical activity on ligaments and tendons. Medicine and Science in Sports 1975;7:165-75

[67]. Barr ML, Kiernan JA (eds). The Human Nervous System: an Anatomical Viewpoint. Philadelphia, PA: Lippincott, 1988.

[68]. O'Brien M. Functional anatomy and physiology of tendons. Clinics in Sports Medicine 1992;11:505.

[69]. Oxlund H. Relationships between the biomechanical properties, composition and molecular structure of connective tissues. Connective Tissue Research 1986;15(1-2):65-72.

[70]. Curwin SL, Stanish WD (eds). Tendinitis: its Etiology and Treatment. Lexington, KT: Collamore Press, 1984.

[71]. Butler DL, Grood ES, Noyes FR, Zernicke RF. Biomechanics of ligaments and tendons. Exercise and Sport Sciences Reviews 1978;6:125-81.

[72]. Kastelic J, Baer E. Deformation in tendon collagen. Symposia of the Society for Experimental Biology 1980;34:397-435

[73]. Selvanetti A, Cipolla M, Puddu G. Overuse tendon injuries: basic science and classification. Operative Techniques in Sports Medicine 1997;5:110-17.

[74]. Benazzo F, Maffulli N. An operative approach to Achilles tendinopathy. Sports Medicine and Arthroscopy Review 2000;8:96-101.

[75]. Ker RF. The implications of the adaptable fatigue quality of tendons for their construction, repair and function. Comparative Biochemistry and Physiology. Part A. Molecular and Integrative Physiology 2002;133:987-1000

[76]. Vailas AC, Tipton CM, Laughlin HL, et al. Physical activity and hypophysectomy on the aerobic capacity of ligaments and tendons. Journal of Applied Physiology 1978;44:542-46.

[77]. 181. Evans CH. Cytokines and the role they play in the healing of ligaments and tendons. Sports Medicine 1999;28:71-6.

[78]. Sciore P, Boykiw R, Hart DA. Semiquantitative reverse transcription-polymerase chain reaction analysis of mRNA for growth factors and growth factor receptors from normal and healing rabbit medial collateral ligament tissue. Journal of Orthopaedic Research 1998;16:429-37.

[79]. Chang J, Most D, Stelnicki E, et al. Gene expression of transforming growth factor beta-1 in rabbit zone II flexor tendon wound healing: evidence for dual mechanisms of repair. Plastic and Reconstructive Surgery 1997;100:937-44.

[80]. Chang J, Most D, Thunder R, et al. Molecular studies in flexor tendon wound healing: the role of basic fibroblast growth factor gene expression. Journal of Hand Surgery 1998;23A:1052-8.

[81]. Woo SL, Hildebrand K, Watanabe N, et al. Tissue engineering of ligaments and tendon healing. Clinical Orthopaedics and Related Research 1999;367:S312-23.

[82]. Natsuume T, Nakamura N, Shino $\mathrm{K}$, et al. Temporal and spatial expression of transforming growth factor-beta in the healing patellar ligament of the rat. Journal of Orthopaedic Research 1997;15:837.

[83]. Marui T, Niyibizi C, Georgescu HI, et al. Effect of growth factors on matrix synthesis by ligament fibroblasts. Journal of Orthopaedic Research 1997;15:18-23.

[84]. Abrahamsson SO, Lohmander S. Differential effects of insulin-like growth factor-I on matrix and DNA synthesis in various regions and types of rabbit tendons. Journal of Orthopaedic Research 1996;14:370-6.

[85]. $\quad$ 84.Sharma P, Maffulli N. Tendinopathy and tendon injury: The future. Disability and Rehabilitation 2008;9:1-13.

[86]. Nirschl RP. Elbow tendinosis/tennis elbow. Clinics in Sports Medicine 1992;11:851-70.

[87]. Calfee RP, Patel A, DaSilva MF, Akelman E. Management of lateral epicondylitis: current concepts. Journal of the American Academy of Orthopaedic Surgeons 2008;16:19-29.

[88]. Goldie I. Epicondylitis lateralis humeri (epicondylalgia or tennis elbow). A pathogenetical study. Acta Chirurgica Scandinavica Supplementum 1964;57(339):1.

[89]. Ciccotti MC, Schwartz MA, Ciccotti MG. Diagnosis and treatment of medial epicondylitis of the elbow. Clinics in Sports Medicine 2004;23:693-705

[90]. Shiri R, Viikari-Juntura E, Varonen H, Heliovaara M. Prevalence and determinants of lateral and medial epicondylitis: a population study. American Journal of Epidemiology 2006;164:1065-74.

[91]. Stockard AR. Elbow injuries in golf.[see comment]. Journal of the American Osteopath Association 2001;101:509-16.

[92]. Jobe F, Ciccotti M. Lateral and medial epicondylitis of the elbow. Journal of the American Academy of Orthopaedic Surgeons 1994;2:1-8

[93]. Ciccotti MC, Schwartz MA, Ciccotti MG. Diagnosis and treatment of medial epicondylitis of the elbow. Clinics in Sports Medicine 2004;23:693-705

[94]. Mercer's Textbook of Orthopaedics and Trauma tenth Edison Turek's orthopaedics $7^{\text {th }}$ edition 95.Textbookk of orthopaedics and trauma, GS K ulkarni Sushrut Babhulkar

[95]. Lewis JS. Rotator cuff tendinopathy/subacromial impingement syndrome: is it time for a new method of assessment? Br J Sports Med 2009;43(4):259-6

[96]. CAROLYN M. SOMMERICH, JAMES D. MCGLOTHLINb \& WILLIAM S. MARRAS. Occupational risk factors associated with soft tissue disorders of the shoulder: a review of recent investigations in the literature. Ergonomics 1993; 36(6): pages 697-717 (level of evidence $2 \mathrm{~A}$ )

[97]. Gaida JE, Ashe MC, Bass SL, Cook JL. Is adiposity an under-recognised risk factor for tendinopathy? A systematic review. Arthr Care Res 2009; 61(6), pages 840-84 
[98]. Abate M, Schiavone C, Salini V, Andia I. Occurrence of tendon pathologies in metabolic disorders. Rheumatology (Oxford). 2013 Apr;52(4):599-608. doi: 10.1093/rheumatology/kes395. Epub 2013 Jan 12

[99]. Cohen R, William G (1998) Impingement syndrome and rotator cuff disease as repetitive motion disorder. Clin Orthop 351:95-100

[100]. Grana W. Medial epicondylitis and cubital tunnel syndrome in the throwing athlete. Clinics in Sports Medicine 2001;20:541-8.

[101]. Ciccotti MC, Schwartz MA, Ciccotti MG. Diagnosis and treatment of medial epicondylitis of the elbow. Clinics in Sports Medicine 2004;23:693-705.

[102]. Boone DC, Azen SP. Normal range of motion of joints in male subjects. Journal of Bone and Joint Surgery (American) 1979;61:756-9.

[103]. Griffin XL, Smith CM, Costa ML: The clinical use of platelet-rich plasma in the promotion of bone healing: A systematic review. Injury 2009;40:158-162.

[104]. Edwards S, Calandruccio J: Autologous bloodinjections for refractory lateral epicondylitis. J Hand Surg Am 2003, 28:272-278.

[105]. Furey JG. Proximal plantar fascitis. The painful heel syndrome. J Bone Joint Surg Am 1975; 57: 672-673

[106]. Molloy T, Wang Y, Murrell G. The roles of growth factors in tendon and ligament healing. Sports Med 2003;33:381-94.

[107]. Creaney L, Hamilton B. Growth factor delivery methods in the management of sports injuries: the state of play. Br J Sports Med. 2008;42:314-320.

[108]. Pizza FX, McLoughlin TJ, McGregor SJ, Calomeni EP, Gunning WT. Neutrophils injure cultured skeletal myotubes. Am J Physiol Cell Physiol2001; $281:$ C335-341.

[109]. Schneider BS, Tiidus PM: Neutrophil infiltration in exercise injured skeletal muscle. Sports Med 2007;37:837-856.

[110]. Scott A, Khan KM, Roberts CR, Cook J, Duronio V. What do we mean by the term "inflammation" ? A contemporarybasic science update for sports medicine. Br J SportsMed $2004 ; 38: 372-380$.

[111]. Michael P. Hall, MD, Phillip A. Band, PhD, Robert J. Meislin. Platelet-rich Plasma: Current Concepts and Application in Sports Medicine. J Am AcadOrthopSurg2009;17: 602-608.

[112]. Marx RE: Platelet-rich plasma: Evidence to support its use. J Oral MaxillofacSurg2004;62:489-496.

[113]. Sánchez M, Anitua E, Azofra J, AndíaI,Padilla S, Mujika I: Comparison of surgically repaired Achilles tendon tears using plateletrich fibrin matrices. Am JSports Med 2007;35:245-251.

[114]. Akhundov, K., Pietramaggiori, G., Waselle, 1., Darwiche, S., Guerid, S Development of a cost-effective method for platelet-rich plasma (PRP) preparation for topical wound healing. Annals of Burns and Fire Disasters. 2012; 25(4), $207-213$.

[115]. Wewers ME, Lowe NK. A critical review of visual analogue scales in the measurement of clinical phenomena. Res Nurs Health. 1990 Aug;13(4):227-36.

[116]. Filardo G, Kon E, Della Villa S, Vincentelli F, Fornasari PM, Marcacci M. Use of platelet- rich plasma for the treatment of refractory jumper's knee. Int Orthop 2010;34:909- 15.

[117]. Gosens T, Den Oudsten BL, Fievez E, van 't Spijker P, Fievez A. Pain and activity levels before and after platelet- rich plasma injection treatment of patellar tendinopathy: A prospective cohort study and the influence of previous treatments. Int Orthop 2012;36:1941- 6 .

[118]. Vetrano M, Castorina A, Vulpiani MC, Baldini R, Pavan A, Ferretti A. Platelet- Rich Plasma Versus Focused Shock Waves in the Treatment of Jumper's Knee in Athletes. Am J Sports Med 2013;41:795- 803.

[119]. AksahinE,DogruyolD, Yukselhy, et al. The comparison of the effect of corticosteroids and platelet-rich plasma (PRP) for the treatment of proximal plantar fascitis. Arch Orthop Trauma Surg. 2012;132:781-785.

[120]. Lee TG, Ahmad TS. Intralesional autologous blood injection compared to corticosteroid injection for treatment of chronic proximal plantar fascitis. A prospective, randomized, controlled trial. Foot Ankle Int. 2007;28(9):984-990.

[121]. Martinelli N, Marinozzi A, Carnì S, Trovato U, Bianchi A, Denaro V. Platelet-rich plasma injections for chronic proximal plantar fascitis. International Orthopaedics. 2013;37(5):839-842.

[122]. O'Malley, M. J., Vosseller, J. T., \&Gu, Y. (2013). Successful Use of Platelet-Rich Plasma for Chronic Proximal plantar fascitis. HSS Journal, 9(2), 129-133.doi:10.1007/s11420-012-9321-9.

[123]. Shetty V, Dhillon M: A study to compare the efficacy of corticosteroid therapy with platelet-rich plasma therapy in recalcitrant proximal plantar fascitis: A preliminary report : foot and ankle sugery.2014;20:10-13.

[124]. Barrett S, Erredge S. Growth factors for chronic proximal plantar fascitis. Podiatry Today. 2004;17:37-42.

[125]. Kumar V, Millar T, Murphy PN, Clough T. The treatment of intractable plantar fascitis with platelet-rich plasma injection.Foot 2013;23(2-3):74-7.

[126]. Werner CO. Lateral elbow pain and posterior interosseous nerve entrapment. Acta Orthopaedica Scandinavica Supplementum 1979;174:1-62.

[127]. Ruch DS, Papadonikolakis A, Campolattaro RM. The posterolateral plica: a cause of refractory lateral elbow pain. Journal of Shoulder and Elbow Surgery 2006;15:367-70.

[128]. Dlabach JA, Baker CL Jr. Lateral and medial epicondylitis in the overhead athlete. Operative Techniques in Orthopaedics. 2001;11:46-54.

[129]. Uden H, Boesch E, Kumar S. Proximal plantar fascitis - to jab or to support? A systematic review of the current best evidence. Journal of multidisciplinary healthcare. 2011;4:155-164. 